\title{
IMPLEMENTASI SISTEM PEMBELAJARAN MOVING CLASS UNTUK MENINGKATKAN PENGELOLAAN SARANA DAN PRASARANA PENDIDIKAN PADA SMP NEGERI 1 SIMPANG MAMPLAM KABUPATEN BIREUEN
}

\author{
Nurmalina \\ IAIN Takengon, Aceh Tengah, Aceh, Indonesia \\ Email: nurmalina125@gmail.com
}

\begin{abstract}
The application of the moving class learning system makes the subject teacher obliged to manage the learning facilities and infrastructure in the class of the field of study. This study intends to understand the moving class learning system's implementation to improve the management of educational facilities and infrastructure in SMP Negeri 1 Simpang Mamplam Kabupaten Bireuen. This study used the descriptive qualitative method. The research subjects in this study were the principal and representatives of the curriculum field and teachers of the field of study. Observation, interview, and documentation study are used to collect the data. The results revealed that the application of the moving class learning system at SMP Negeri 1 Simpang Mamplam was: (a) learning facilities and infrastructure are better maintained; (b) the provision of learning facilities can be tailored to the needs of learning media in each field of study; (c) the subject teacher is responsible for the learning facilities in his class; d) damage to learning facilities and infrastructure can be minimized; (e) the subject teacher tries to create an attractive and pleasant classroom atmosphere by creating wall magazine creations, reading corners, various seating, and providing hanging folders for student work in the class, with the hope that students feel happy and motivated in learning which will ultimately have an impact on improving the quality of SMP Negeri 1 Simpang Mamplam Kabupaten Bireuen.
\end{abstract}

Keywords: Moving Class Learning System, Educational Facilities And Infrastructure

\begin{abstract}
Abstrak: Penerapan sistem pembelajaran moving class menjadikan guru bidang studi berkewajiban terhadap pengelolaan sarana dan prasarana pembelajaran dikelas bidang studi yang diampunya. Penelitian ini bermaksud untuk memahami implementasi sistem pembelajaran moving class untuk meningkatkan pengelolaan sarana serta prasarana pendidikan pada SMP Negeri 1 Simpang Mamplam Kabupaten Bireuen. Penelitian ini menggunakan metode deskriptif kualitatif. Yang menjadi subjek penelitian pada penelitian ini yaitu kepala sekolah dan wakil bidang kurikulum serta guru bidang studi. Metode penghimpunan data dengan observasi, interview serta studi dokumentasi. Hasil penelitian mengungkapkan bahwa penerapan sistem pembelajaran moving class di SMP Negeri 1 Simpang Mamplam adalah: (a) sarana dan prasarana pembelajaran lebih terpelihara; (b) pengadaan sarana pembelajaran dapat disesuaikan dengan kebutuhan media pembelajaran masing-masing bidang studi; (c) guru bidang studi menjadi penanggung jawab sarana pembelajaran di kelasnya; (d) kerusakan sarana dan prasarana pembelajaran dapat diminimalisir; (e) guru bidang studi berusaha mewujudkan suasana kelas yang memikat dan menyenangkan dengan membuat kreasi mading, pojok baca, tempat duduk yang bervariasi, serta penyediaan map gantung untuk hasil kerja siswa dikelas tersebut, dengan harapan peserta didik merasa senang dan termotivasi dalam belajar yang pada akhirnya akan berdampak kepada peningkatan mutu SMP Negeri 1 Simpang Mamplam Kabupaten Bireuen.
\end{abstract}

Kata Kunci: Sistem Pembelajaran Moving Class, Sarana Prasarana Pendidikan

\section{PENDAHULUAN}

Manajemen pendidikan ialah suatu kegiatan pengelolaan pendidikan yang sangat diperlukan oleh setiap sekolah, yang dimulai dari perencanaan, pengorganisasian, 
pelaksanaan serta pengawasan. Setiap sekolah harus membuat perencanaan yang baik pada pelaksanaannya, sehingga dapat menghasilkan lulusan yang bermutu dan berkarakter mulia. Sebagaimana pendidikan yang disebutkan pada Undang-Undang Nomor 20 tahun 2003 tentang Sistem Pendidikan Nasional yaitu Pendidikan merupakan satu upaya sadar serta terencana dalam menciptakan kondisi belajar dan strategi pembelajaran supaya siswa dengan aktif dapat menumbuhkan potensi dirinya untuk mendapat kemampuan spiritual keagamaan, pengelolaan diri, budi pekerti, kecerdikan, akhlak mulia, dan keahlian yang dibutuhkan dirinya, masyarakat, bangsa serta negara.

Bidang garapan manajemen pendidikan pada tataran sekolah menengah pertama terdiri dari manajemen kurikulum, manajemen peserta didik, manajemen sarana dan prasarana, manajemen kelas, manajemen pendidik dan tenaga kependidikan, manajemen pembiayaan, manajemen layanan publik. Semua bidang garapan manajemen saling menyempurnakan untuk menjadikan sekolah tersebut bermutu dan berdaya saing sehingga dapat menghasilkan lulusan yang berkompetensi. Sarana dan prasarana pada sebuah lembaga pendidikan merupakan alat penggerak untuk mencapai tujuan pendidikan yang telah ditetapkan.

Sarana dan prasarana pendidikan ialah salah satu faktor utama yang mendukung terlaksananya pembelajaran pada sekolah. Sarana pendidikan yaitu fasilitas yang digunakan langsung pada proses belajar mengajar, seperti spidol, meja, tempat duduk, white board. Sementara itu yang diartikan dengan prasarana yaitu fasilitas penunjang untuk terlaksananya proses pembelajaran, seperti tanah, gedung, jalan masuk menuju sekolah, lapangan. Sarana serta prasarana pendidikan membutuhkan pengelolaan yang baik, karena itu perlu dikelola oleh orang yang kompeten dalam bidang sarana tersebut, sehingga kepala sekolah membutuhkan strategi dalam memajemen sarana serta prasarana sekolah yang dimilikinya. Manajemen sarana serta prasarana pendidikan ialah segenap proses aktivitas yang diprogramkan dan diupayakan secara sengaja dan mendalam serta pemeliharaan secara terus menerus pada fasilitas pendidikan, supaya selalu bisa digunakan dalam proses pembelajaran (Daryanto, 2013: 143). Kepala sekolah harus mempunyai strategi pada pengelolaan sarana serta prasarana pendidikan di sekolah, supaya proses pembelajaran bisa berjalan baik serta lancar.

Pengelolaan sarana serta prasarana pendidikan merupakan tanggung jawab semua warga sekolah. Untuk itu kepala sekolah harus menerapkan berbagai strategi dalam 
pengelolaan sarana serta prasarana pendidikan pada sekolah yang dipimpinnya. Suatu strategi yang digunakan kepala SMP Negeri 1 Simpang Mamplam Kabupaten Bireuen pada pengelolaan sarana serta prasarana pendidikan yaitu dengan menerapkan sistem pembelajaran moving class. Sistem pembelajaran moving class ialah salah satu sistem pembelajaran yang mana peserta didiknya yang berpindah kelas saat pergantian mata pelajaran dan guru bidang studi tersebut sudah menuggu di kelas, semua kelas sudah dilengkapi dengan fasilitas dan media pembelajaran yang diperlukan pada mata pelajaran tersebut.

Sistem pembelajaran moving class mengharuskan guru bidang studi selalu berada di kelas mata bidang studi mereka. Semua sarana, prasarana, tata kelola kelas, keindahan dan kebersihan kelas tersebut amenjadi tanggung jawab guru bidang studi. Karena itu penulis ingin meneliti tentang sistem pembelajaran moving class yang diterapkan pada SMP Negeri 1 Simpang Mamplam Kabupaten Bireuen.

\section{LANDASAN TEORI}

\section{Manajemen Sarana dan Prasarana Pendidikan}

Sarana dan prasarana pendidikan ialah salah satu fasilitas utama yang diperlukan instansi pendidikan dalam mencapai tujuan pendidikan. Sarana pendidikan pada dasarnya meliputi seluruh fasilitas yang dengan langsung difungsikan serta mendukung pada proses jalannya pendidikan, seperti: bangunan kantor, gedung belajar/kelas, perangkat/media pembelajaran, meja, tempat duduk, dan selainnya. Sedangkan prasarana ialah fasilitas yang mendukung secara tidak langsung pada jalannya sistem pendidikan, seperti: lapangan, taman sekolah, jalan masuk ke sekolah. Pada dasarnya Sarana serta prasarana pendidikan bisa dikelompokkan kedalam empat golongan yaitu lahan, bangunan, fasilitas, dan peralatan sekolah (site, building, equipment, and furniture).

Sarana serta prasarana pendidikan hendaklah dikelola dengan baik dan benar supaya pemanfaatannya lebih efektif dan efisien. Pengelolaan sarana serta prasarana pendidikan mencakup: (1) Perencanaan, (2) Pengadaan, (3) Inventarisasi, (4) Penyimpanan, (5) Pemeliharaan, dan (6) Penghapusan. Sebagaimana yang diungkapkan oleh Matin sarana dan prasarana pendidikan ialah suatu sumber kekuatan yang dibutuhkan dalam mendukung proses pembelajaran di sekolah. Suksesnya rancangan pendidikan pada sekolah banyak disebabkan karena keadaan sarana serta prasarana 
pendidikan yang berada di sekolah, pengaturan serta penggunaan sarana dan prasarana tersebut secara maksimal (Matin, 2016: 1).

Dengan demikian dapat kita simpulkan bahwa manajemen sarana prasarana ialah suatu proses kerja sama dalam upaya mendapatkan hasil dan manfaat dari seluruh sarana dan prasarana pendidikan secara efektif dan efesien. Setiap sarana prasarana sekolah harus dimanfaatkan dan dikelola untuk keperluan belajar mengajar, supaya sarana prasarana sekolah dapat berfungsi secara maksimal sehingga dapat meningkatkan mutu pendidikan.

Sarana dan prasarana pendidikan pada sistem pembelajaran moving class ialah sarana dan prasarana pendidikan yang dimanfaatkan langsung pada saat pembelajaran, atau disebut juga dengan sarana prasarana pembelajaran. Sarana pembelajaran merupakan semua perangkat yang digunakan langsung pada proses pelaksanaan pendidikan pada sekolah yang mendukung terwujudnya salah satu sasaran pembelajaran yang sudah ditetapkan. Sarana pembelajaran berperan untuk mendukung kelancaran dalam mewujudkan kegiatan pendidikan pada sekolah dan membantu tenaga pengajar dan peserta didik pada proses belajar mengajar. Sarana pembelajaran terdiri dari: (1) Fasilitas pelajaran, seperti: buku pegangan, LKS, bahan ajar, fasilitas praktik, serta alat tulis. (2) Fasilitas peraga, seperti: bangun datar, bangun ruang, kerangka manusia, peta dan globe. (3) Alat pengajaran, adalah fasilitas pendidikan yang berperan menjadi penghubung pada proses pembelajaran yang selanjutnya dapat menumbuhkan efektivitas serta efisiensi untuk mewujudkan sasaran pembelajaran. Alat pembelajaran terdiri dari tiga model, (a) Alat pembelajaran visual, seperti: sketsa, poster, gambar, bagan skematis, (b) Alat pembelajaran audio, seperti: radio, (c) Alat pembelajaran audiovisual, seperti: video.

Sedangkan, prasarana pembelajaran merupakan semua instrumen kelengkapan dasar yang mendukung pelaksanaan sistem pendidikan di sekolah secara tidak langsung. Prasarana pembelajaran juga dapat diartikan selaku perangkat tidak langsung yang dipakai dalam mewujudkan tujuan pendidikan, seperti ruangan kelas, gedung sekolah, tempat olahraga, kantin, sarana beribadah.

\section{Sistem Pembelajaran Moving Class}

Sistem adalah satu kesatuan yang saling berhubungan agar dapat mencapai sasaran yang sudah ditetapkan. Sistem merupakan gabungan komponen-kompnen yang saling berkaitan dan bergantung serta disusun sedemikian rupa supaya melahirkan suatu keseluruhan (Kadarman, 1996: 8). Sistem ialah sekelompok elemen-elemen yang bekerja 
sama menjadi satu kesatuan fungsi (Syafaruddin dan Irwan Nasution, 2005: 42). Jadi sistem merupakan sesuatu yang berkaitan untuk bekerjasama dalam mencapai tujuan.

Sedangkan pembelajaran ialah cara komunikasi dua arah, dimana pihak guru selaku pendidik yang melaksanakan pengajaran, dan siswa sebagai peserta didik yang melaksanakan kegiatan belajar (Sagala, 2005: 61). Pembelajaran merupakan proses hubungan siswa dengan guru serta sumber belajar di suatu lingkungan sekolah (UU RI No 20 Tahun 2003). Dengan begitu pembelajaran ialah suatu proses dimana guru dan siswa saling berinteraksi dalam mencapai sasaran pembelajaran. Jadi yang dimaksud dengan sistem pembelajaran ialah suatu proses yang saling mempengaruhi antara siswa dengan guru untuk menumbuhkan kreativitas berpikir dalam proses pembelajaran nantinya sehingga dapat tercapai sasaran yang diinginkan.

Berdasarkan kamus Moving class artinya kelas bergerak. Moving class merupakan suatu sistem pembelajaran yang diciptakan dengan tujuan belajar aktif serta kreatif (John dan Sadily, 1977: 387). Pada sistem pembelajaran bercirikan peserta didik yang mengunjungi guru di ruangan kelas, bukan sebaliknya (Sagala, 2009: 183). Konsep pembelajaran moving class pada dasarnya adalah memudahkan untuk peserta didik dalam menguasai materi pelajaran yang hendak diberikan karena dalam kelas telah dilengkapi dengan sarana dan media serta sumber lain yang diperlukan sehingga pendidik tidak kesulitan dalam menata ruang dan menata media pembelajarannya seperti sebuah laboratorium. Pada sistem moving class ini di dalam kelas sudah tersedia model-model pembelajaran yang siap digunakan sehingga guru tidak perlu lagi mencari sarana pembelajaran yang akan digunakan, guru dapat menggunakannya sesuai materi yang akan dipelajari bersama peserta didiknya.

\section{METODE PENELITIAN}

Metode penelitian yang dimanfaatkan untuk penelitian ini ialah penelitian deskriptif kualitatif, merupakan penelitian yang memaparkan kondisi sebenarnya di lapangan, berupaya untuk mengungkapkan serta mengetahui kejadian sebenarnya yang berlansung di lapangan terhadap implementasi sistem pembelajaran moving class untuk meningkatkan pengelolaan sarana serta prasarana pendidikan pada SMP Negeri 1 Simpang Mamplam Kabupaten Bireuen.

Penghimpunan data yang dipakai untuk penelitian ini yaitu observasi, interview, serta studi dokumentasi. Menurut Sugiyono (2014: 62) langkah yang paling utama dalam 
penelitian ialah teknik penghimpunan data karena bertujuan untuk memperoleh data yang mewujudkan standar data yang ditentukan. Pada penelitian ini peneliti melakukan wawancara dengan kepala sekolah, wakil bidang kurikulum dan guru bidang studi di SMP Negeri 1 Simpang Mamplam Kabupaten Bireuen.

Penelitian ini melakukan analisis data dengan Analysis Interactive model dari Miles dan Huberman dengan prosedur sesuai tahapan mereduksi data, menyajikan data dan menarik kesimpulan. Sebagaimana yang dinyatakan Sugiyono (2014: 246) bahwa kegiatan dalam analisis data kualitatif dikerjakan dengan cara interaktif dan berjalan secara kontinu hingga tuntas, sampai datanya telah jenuh.

\section{HASIL DAN PEMBAHASAN}

\section{Implementasi Sistem Pembelajaran Moving Class}

Berdasarkan hasil observasi yang penulis lakukan pada SMP Negeri Simpang Mamplam bahwa sekolah tersebut sudah menerapkan sistem pembelajaran moving class. Hal ini terlihat dari ruangan kelas yang sudah dinamai dengan nama mata pelajaran, sarana prasarana pembelajaran yang tersedia didalamnya sesuai dengan mata pelajaran kelas tersebut serta guru bidang studi yang sesuai mata pelajaran tersebut juga berada di kelas. Hasil wawancara dengan salah satu guru bidang studi "setelah penerapan sistem pembelajran moving class kami guru bidang studi berkantor di kelas mata pelajaran kami, kami bertanggung jawab terhadap sarana prasarana yang ada dikelas ini serta kami berkewajiban dalam membuat kelas ini menarik untuk siswa belajar".

Sistem pembelajaran moving class diterapkan oleh SMP Negeri 1 Simpang Mamplam salah satu tujuannya untuk meningkatkan pengelolaan sarana prasarana yang ada di kelas. Untuk menerapkan sistem pembelajaran baru pada suatu sekolah perlu adanya musyawarah antara pihak sekolah dengan masyarakat setempat. Karena itu kepala sekolah SMP Negeri 1 Simpang Mamplam mengadakan rapat bersama dewan guru serta komite untuk membicarakan penerapan sistem pembelajaran moving class ini. Sebagaimana hasil wawancara dengan kepala sekolah yaitu "sebelum kami menerapkan sistem pembelajaran moving class, saya mengundang komite sekolah sebagai wakil masyarakat setempat untuk memusyawarahkan penerapan sistem pembelajaran ini. Dalam rapat tersebut kami membahas tentang kelebihan dari sistem pembelajaran moving class dan hal-hal yang perlu disiapkan pada proses pembelajaran nantinya”. 
Hal yang sama juga dikatakan oleh wakil kepala sekolah pada wawancara "pihak sekolah mengundang komite sekolah untuk membahas persiapan yang perlu dilakukan dalam menyiapkan sistem pembelajaran moving class bersama dewan guru sekolah ini dan juga sekolah menyediakan bahan-bahan yang diperlukan guru bidang studi dalam menyiapkan kelasnya".

Dalam penerapan sistem pembelajaran diperlukan persiapan dari sekolah, dewan guru, komite sekolah dan peserta didiknya. Persiapan pertama yang perlu dilakukan berupa pembinaan kepada guru bidang studi, karena merekalah penggerak utama dalam sistem pembelajaran moving class ini. Para guru bidang studi harus melakukan persiapan kelas bidang studi masing-masing antara lain persiapan sarana dan prasarana pembelajaran yang sesuai dengan bidang studinya serta membuat suasana kelas yang menarik supaya siswa termotivasi dalam belajar.

Sistem pembelajaran moving class dilaksanakan untuk meningkatkan motivasi peserta didik untuk belajar, peserta didik yang sering mengantuk, tidak fokus dalam pelajaran sehingga diharapkan dengan adanya sistem pembelajaran moving class ini semua kebiasaan jelek tersebut dapat hilang karena peserta didik akan merasa segar kembali dengan suasana kelas yang berbeda pada tiap mata pelajaran. Selain itu dengan menerapkan sistem pembelajaran moving class, guru bidang studi diberi kepercayaan dalam mengelola serta menggunakan sarana dan prasarana sekolah, karena sarana yang berhubungan dengan bidang studinya akan berada dikelas mata pelajarann yang diampunya sehingga guru bidang studi lebih bijaksana dalam memanfaatkan sarana pendidikan tersebut.

Sebagaimana hasil wawancara dengan guru bidang studi pada SMP Negeri 1 Simpang Mamplam Kabupaten Bireuen mengatakan bahwa "Dengan pelaksanaan sistem moving class ini sarana prasarana sekolah yang berkaitan dengan bidang studi yang diampunya lebih terjaga karena selalu dapat di pantau".

Implementasi sistem pembelajaran moving class menjadikan siswa lebih termotivasi dalam belajar karena suasana kelas pada setiap mata pelajaran akan berbeda dan sarana serta media pembelajaran lebih bervariasi sesuai dengan mata pelajaran yang akan dipelajari dikelas tersebut. Ekwanis Putrielis (2017:127) menyebutkan bahwa "moving class yang memapunyai karakteristik sesuai dengan bidang studi pelajaran secara sengaja dapat mengajak peserta didik untuk menarik perhatian kepada materi yang diberikan pada saat proses belajar mengajar, karena sarana prasarana pembelajaran sudah 
ada dalam kelas". Proses pembelajaran yang mendapat perhatian serius dari peserta didik akan dapat meningkatkan motivasi belajar peserta didik sehingga berdampak pada peningkatan prestasi belajar.

Hal ini juga disampaikan oleh Kepala SMP Negeri 1 Simpang Mamplam Kabupaten Bireuen bahwa "Dengan menerapkan sistem pembelajaran moving class guru dan siswa dapat lebih terfokus dalam mata pelajaran dikelas tersebut karena semua media dan alat peraga yang diperlukan berada di ruangan, guru bidang studi bertanggung jawab penuh terhadap ruang kelas mata pelajaran tersebut.” Dengan demikian implementasi sistem pembelajaran moving class mengharuskan guru bidang studi pada SMP Negeri 1 Simpang Mamplam bertanggung jawab terhadap kelas mata pelajarannya, dan semua sarana serta prasarana pembelajaran yang berkaitan pada bidang studi yang berada dikelas tersebut, sehingga pada saat proses pembelajaran siswa dan guru lebih fokus dan termotivasi dalam belajar.

\section{Pengelolaan Sarana dan Prasarana Pendidikan Pada Sistem Pembelajaran Moving Class}

Sarana dan prasarana pembelajaran menjadi tanggung jawab sekolah dalam penyediaannya, namun dalam pengelolaannya menjadi tanggung jawab semua warga sekolah. Karena itu kepala sekolah SMP Negeri 1 Simpang Mamplam menerapkan sistem pembelajaran moving class sebagai salah satu strategi untuk memudahkan dalam pengelolaan sarana prasarana pembelajaran.

Berdasarakan hasil wawancara dengan kepala sekolah SMP Negeri 1 Simpang Mamplam Kabupaten Bireuen mengatakan bahwa "pengelolaan sarana dan prasarana pembelajaran dengan sistem pembelajaran moving class lebih efektif dan efisien, karena guru bidang studi langsung yang mengelola sarana prasarana pembelajaran tersebut, jadi para guru bidang studi mengetahui sarana apa yang perlu diadakan, perlu perawatan dan sarana apa yang masih kurang dalam bidang studinya. Dengan demikian pihak sekolah lebih mudah merencanakan, mengadakan, menginventarisasi, perawatan, dan penghapusan apabila barang sudah tidak bisa dipergunakan lagi”. Jadi kepala sekolah lebih mudah pada pengelolaan sarana dan prasarana pendidikan di sekolahnya dengan menerapkan sistem pembelajaran moving class.

Hal tersebut juga diungkapkan oleh guru bidang studi SMP Negeri 1 Simpang Mamplam Kabupaten Bireuen yaitu "Dengan sistem pembelajaran moving class sarana dan prasarana pembelajaran yang terdapat di kelas cocok dengan bidang studi yang akan 
dipelajari siswa, kami para guru bidang studi lebih mudah mengelolanya dan melaporkan keadaan sarana tersebut kepada pihak sekolah". Pada sistem pembelajaran moving class pengelolaan sarana dan prasarana pembelajaran khususnya, lebih terkontrol karena dikelola langsung oleh guru bidang studi.

Jadi pengelolaan sarana dan prasarana pembelajaran pada sistem pembelajaran moving class membantu sekolah dalam pengelolaannya dan juga membantu guru pada proses pembelajaran di kelas, karena sarana dan prasarana pembelajaran yang diperlukan berada di kelas mata pelajaran masing-masing dan menjadi tanggung jawab guru bidang studi dalam pemeliharaan serta penggunaannya. Dengan demikian dalam pengelolaan sarana prasarana pembelajaran perlu ditangani oleh orang yang ahli dalam bidangnya dalam hal ini ialah guru bidang studi, agar sarana prasarana pembelajaran tersebut dapat berfungsi dengan baik serta dapat digunakan pada saat dibutuhkan. Nasrudin dan Maryadi (2018: 20) menyatakan bahwa "Sarana dan prasarana pembelajaran yang telah terkondisikan dengan baik dapat menunjang kegiatan belajar mengajar secara baik". Karena itu pengelolaan sarana dan prasarana pembelajaran sebaiknya berada pada ahlinya, karena orang yang ahli dibidang tersebut yang bisa memfungsikan sarana tersebut secara maksimal.

\section{Meningkatkan Pengelolaan Sarana dan Prasarana Penddikan dengan menerapkan sistem Pembelajaran Moving Class}

Pengelolaan sarana dan prasarana pendidikan merupakan kewajiban sekolah, karena pihak sekolah lah yang paling tahu akan kebutuhan fasilitas dan kelengkapan yang diperlukan dan yang sangat diperlukan sekolah sekarang. Tanpa mengenyampingkan pengawasan dari pihak dinas pendidikan kabupaten dan provinsi. Pada pengelolaan sarana serta prasarana pendidikan pihak sekolah juga harus mengikuti juknis pengelolaan dana pengadaan, pemeliharaan yang telah ditetapkan pemerintah.

Pihak sekolah yang berkewajiban penuh terhadap sarana dan prasarana pendidikan adalah kepala sekolah selaku pimpinan. Karena itu kepala sekolah harus kreatif dan inovatif dalam mengatur sumber daya pendidik dan kependidikan serta sumber daya fisik yang terdapat di sekolahnya. Sebagaimana dikatakan oleh Wahjosumijo bahwa kepemimpinan adalah salah satu kekuatan yang berharga dalam rangka pengaturan, karenanya keahlian memimpin dengan cara efektif adalah kunci dalam melahirkan seorang manager yang efektif (Wahjosumidjo, 2013: 104). 
Kepala sekolah selaku seorang pemimpin serta manager di sekolah, oleh sebab itu dalam pengelolaan sarana serta prasarana pendidikan kepala sekolah hendaklah mempunyai strategi untuk meningkatkan pengelolaannya dengan mengikutkan semua warga sekolah terutama guru. Menurut Daryanto pengelolaan sarana serta prasarana pendidikan memerlukan keterampilan khusus seperti pengurusan fasilitas transportasi, komputer, jaringan internet, telepon, listrik, air bersih, perpustakaan, UKS, laboratorium, koperasi, konsumsi/gizi (Daryanto, 2013: 144). Dari pernyataan ini sangat tepat apabila sarana dan prasarana pembelajaran dikelola langsung guru bidang studi, sehingga sarana yang diperlukan pada proses belajar mengajar mata pelajaran tersebut seperti alat peraga dan media pembelajaran dapat terkelola dengan efektif dan efisien.

Penerapan sistem pelmbelajaran moving class merupakan salah satu strategi kepala sekolah SMP Negeri 1 Simpang Mamplam Kabupaten Bireuen untuk mengikutkan guru bidang studi dalam pengelolaan sarana serta prasarana pembelajaran. Menurut hasil wawancara bersama kepala sekolah menyatakan bahwa "Dengan penerapan sistem pembelajaran moving class sarana dan prasarana lebih terjaga karena dapat dipantau langsung oleh guru dalam pemanfaatannya, dan dalam pengadaan sarana pembelajaran sesuai dengan kebutuhan pembelajaran masing-masing bidang studi, guru bidang studi bertanggung jawab terhadap sarana dan prasarana pembelajaran dikelas mata pelajaran tersebut dan dapat meminimalisir kerusakan karena dikontrol langsung dalam penggunaanya oleh guru bidang studi pada saat pelajaran berlangsung, dan guru bidang studi berusaha menciptakan suasana kelas yang menarik supaya siswa merasa senang dan termotivasi dalam belajar".

Kepala sekolah sangat berperan dalam keberhasilan pengurusan sarana dan prasarana pembelajaran agar semua fasilitas dan perlengkapan di sekolah digunakan secara tepat guna dan oleh sumber daya yang kompeten dalam bidangnya, sehingga berbagai strategi digunakan dalam pelaksanaannya. Para guru bidang studi berusaha menciptakan suasana kelas yang berbeda dari setiap mata pelajaran yang ditekuni peserta didiknya sehingga pada setiap kelas peserta didik mendapat suasana belajar yang berbeda dan menyenangkan. Kepala sekolah mengapresiasi guru dalam mencitptakan suasana kelas yang menarik dengan menyediakan bahan-bahan yang dibutuhkan. Memberi motivasi kepada guru dalam meningkatkan kinerjanya sangat diperlukan seperti yang dikatakan oleh Mulyasa usaha kepala sekolah yang dapat dilakukan dalam menumbuhkan 
kinerja sekolah yaitu dengan pembinaan disiplin guru, memberi dorongan motivasi, pemberian apresiasi, dan persepsi (Mulyasa, 2013: 141).

Penerapan strategi sistem pembelajaran moving class ini dapat meningkatkan pengelolaan sarana serta prasarana di SMPN 1 Simpang Mamplam Kabupaten Bireuen yaitu pengelolaan sarana dan prasarana pembelajaran yang berada dikelas mata pelajaran menjadi tanggung jawab guru bidang studi, baik itu analisis kebutuhan, pemeliharaan, penggunaan maupun penghapusan sarana dan prasarana yang tidak bisa digunakan lagi. Hal ini juga tidak terlepas dari pengontrolan kepala sekolah dan wakil bidang sarana dan prasarana SMP Negeri Simpang Mamplam. Sebagaimana hasil wawancara dengan wakil kepaa sekolah yaitu "Sarana prasarana pembelajaran yang menjadi tanggung jawab guru bidang studi kelas juga tidak terlepas dari pegontrolan kami sebagai pihak sekolah dalam pengelolaan utamanya, hal ini seperti analisis kebutuhan sebelum pengadaan sarana prasarana dan penginventarisasi semua sarana yang berada di kelas, namun dengan adanya penerapan sistem pembelajaran moving class ini semua sarana dan prasarana pembelajaran lebih terkontrol, dan penggunaannya lebih tepat sesuai dengan yang dibutuhkan bidang studi masing-masing”.

Dari hasil wawancara tersebut dapat kita simpulkan bahwa dengan penerapan sistem pembelajaran ini guru bidang studi sangat membantu dalam pengelolaan sarana dan prasarana pembelajaran, penggunaanya juga lebih tepat guna karena langsung dikendalikan oleh ahlinya dalam hal ini guru bidang studi masing-masing pelajaran. Hal ini diharapkan seterusnya dapat berdampak kepada peningkatan mutu sekolah.

\section{KESIMPULAN}

Dalam menerapkan sistem pembelajaran moving class harus mendapat dukungan dari semua guru, tenaga adminstrasi, komite sekolah serta masyarakat setempat. Penerapan Sistem pembelajaran moving class pada SMP Negeri 1 Simpang Mamplam Kabupaten Bireuen dapat meningkatkan pengelolaan sarana dan prasarana pendidikan yaitu pengelolaan sarana dan prasarana pembelajaran dikelas menjadi tanggung jawab guru bidang studi, analisis kebutuhan sarana dan prasarana pembelajaran lebih terperinci, penggunaan sarana dan prasarana pembelajaran dikendalikan langsung oleh guru bidang studi sehingga dapat lebih efektif dan efisien dalam penggunaannya, dapat meminimalisir kerusakan terhadap sarana prasarana pembelajaran, dan guru bidang studi berusaha membuat kelasnya semenarik mungkin untuk dapat memotivasi siswa dalam belajar. 


\section{DAFTAR PUSTAKA}

Bafadal, I. (2014). Manajemen Perlengkapan Sekolah: Teori dan Aplikasinya. Jakarta: Bumi Aksara.

Basri, H., \& Tatang, S. (2015). Kepemimpinan Pendidikan. Bandung: Pustaka Setia.

Daryanto. (2013). Administrasi dan Manajemen Sekolah. Jakarta: Rineka Cipta.

Direktorat Pembinaan Tenaga Kependidikan Kementerian Pendidikan dan Kebudayaan. (2019). Modul Pelatihan Penguatan Kepala Sekolah Pengelolan Sarana dan Prasarana Sekolah. Jakarta: Direktorat Pembinaan Tenaga Kependidikan Kementerian Pendidikan dan Kebudayaan.

Echols, J. E \& Sadily, H. (2014). Kamus Inggris, Indonesia. I. Jakarta: Gramedia Pustaka Utama.

Hidayah, A. S., Sulistyarini, Syahrudin, H. (2013). Pengaruh Penerapan Pembelajaran Sistem Moving Class Terhadap Motivasi Belajar Siswa. Jurnal Pendidikan dan Pembelajaran Khatulistiwa, 2(1), 509. https://jurnal.untan.ac.id/index.php/jpdpb/article/view/509

Jayanti, D. L. I. (2017). Implementasi Sistem Moving Class untuk meningkatkan prestasi belajar siswa di SMP Negeri Model Terpadu Bojonegoro. Jurnal Inspirasi Manajemen Pendidikan, 5(1), 21210. https://jurnalmahasiswa.unesa.ac.id/index.php/inspirasi-manajemenpendidikan/article/view/21210

Kadarman, AM., \& Udaya, J. (1996). Pengantar Ilmu Manajemen. Jakarta: Gramedia Pustaka Utama.

Machali, I. (2018). Statistik Manajemen Pendidikan. Yogyakarta: Prodi Manajemen Pendidikan Islam dan Perkumpulan Program Studi Manajemen Pendidikan Isam (PPMPI).

Matin \& Fuad, N. (2016). Manajemen Sarana dan Prasarana Pendidikan Konsep dan Aplikasinya. Jakarta: Raja Grafindo Persada.

Miles, M.B \& Huberman, A. (2007). Analisis Data Kualitatif Buku Sumber tentang Metode-Metode Baru. Terjemahan Tjetjep Rohendi Rohisi. Jakarta: Universitas Indonesia.

Mulyasa, E. (2013). Menjadi Kepala Sekolah Profesional. Bandung: Remaja Rosda Karya.

Moleong, L. J. (2010). Metode Penelitian Kualitatif. Bandung: Rosda Karya.

Nasrudin \& Maryadi. (2018). Manajemen Sarana dan Prasarana Pendidikan Dalam Pembelajaran di SD. Jurnal Managemen Pendidikan, 13(1), 15-23. 
http://journals.ums.ac.id/index.php/jmp/article/view/6363

Nurabadi, A. (2014). Manajemen Sarana dan Prasarana. Malang: Fakultas Ilmu Pendidikan Universitas Negeri Malang.

Putrielis, E. (2017). Keterkaitan Penggunaan Moving Class Dengan Motivasi Belajar dan Dampaknya Terhadap Kepuasan Belajar Ekonomi Siswa MAN 2 Model Pekanbaru. Pekbis Jurnal, 9(2), 125-139.

https://media.neliti.com/media/publications/164371-ID

Rohiat. (2010). Manajemen Sekolah Teori Dasar dan Praktik. Bandung: Refika Aditama.

Rusman. (2012). Model-model Pembelajaran Mengembangkan Profesional Guru. Jakarta: Raja Grafindo Persada.

Sagala, S. (2005). Konsep dan Makna Pembelajaran. Bandung: Alfabeta.

Sagala, S. (2009). Kemampuan Professional Guru dan Tenaga Kependidikan. Bandung: Alfabeta.

Sanjaya, A. (2015). Model-Model Pembelajaran. Jakarta: Bumi Aksara.

Sugiyono. (2014). Metode Penelitian Kuantitatif, Kualitatif dan R\&D, 14th Edition. Bandung: Alfabeta.

Susanto, A. (2016). Konsep, Strategi, dan Implementasi Manajemen Peningkatan Kinerja Guru. Jakarta: Prenadamedia Group.

Syafaruddin \& Nasution, I. (2005). Manajemen Pembelajaran. Ciputat: Ciputat Press.

Tim Dosen Administrasi Pendidikan Universitas Pendidikan Indonesia. (2015). Manajemen Pendidikan. Bandung: Alfabeta.

Undang-undang Republik Indonesia. (2003. Undang-undang Republik Indonesia No.20 Tahun 2003 Tentang Sistem Pendidikan Nasional. Jakarta: Sekretaris Negara Republik Indonesia.

Usman, H. (2013). Manajemen Teori, Praktik, dan Riset Pendidikan. Jakarta: Bumi Aksara.

Wahjosumidjo. (2013). Kepemimpinan Kepala Sekolah Tinjauan Teoritik dan Permasalahannya. Jakarata: Raja Grafindo Persada. 